\title{
Control of Abnormal Metal-Protein Interactions in Neurodegenerative Disorders by Metallothionein-3
}

\author{
Gabriele Meloni§* and Milan Vašák* \\ §SCS Poster Prize Winner
}

\begin{abstract}
In the brain, zinc and copper homeostasis is regulated by a small metalloprotein, metallothionein-3 ( $\left.\mathrm{Zn} \mathrm{n}_{7} \mathrm{MT}-3\right)$, which is down-regulated in neurodegenerative diseases such as Alzheimer (AD), Creutzfeldt-Jacob and Parkinson. These disorders share common pathological hallmarks including misfolding of amyloid- $\beta(A \beta)$, prion protein and $\alpha$-synuclein, the formation of protein aggregates, abnormal metal-protein interactions and oxidative stress. In $\mathrm{AD}, \mathrm{Cu}(\mathrm{II})$ and $\mathrm{Zn}(\mathrm{II})$ are involved in the disease progression by modulating the formation and toxicity of soluble and insoluble oligomers and aggregates of the $A \beta$ peptide. Whereas the copper-induced $A \beta$ aggregation is related to the ROS production and neurotoxicity, the zinc-induced $A \beta$ aggregation is considered neuroprotective. The protective effect of extracellular $Z n_{7} M T-3$ from $A \beta$ toxicity in neuronal cell cultures is not understood. We show that $\mathrm{Zn}_{7} \mathrm{MT}-3$ not only scavenges free $\mathrm{Cu}(I)$ ions, but also removes $\mathrm{Cu}(\mathrm{II})$ bound to $\mathrm{A} \beta$. A metal swap between $\mathrm{Zn}_{7} \mathrm{MT}-3$ and soluble and aggregated $\mathrm{A} \beta-\mathrm{Cu}(\mathrm{II})$ is the underlying molecular mechanism by which the ROS production and related cellular toxicity is abolished. In this process, copper is reduced by the protein thiolates forming $\mathrm{Cu}()_{4} \mathrm{Zn}_{4} \mathrm{MT}-3$, in which an air stable $\mathrm{Cu}()_{4}$-thiolate cluster and two disulfide bonds are present. To examine whether the discovered effect represents a general protective role of this protein in other metal-linked neurodegenerative pathologies, similar studies using prion peptides in complex with $\mathrm{Cu}(I I)$ were conducted. $\mathrm{Zn}_{7} \mathrm{MT}-3$ by a similar metal swap reaction removes abnormally bound $\mathrm{Cu}(I)$ from the prion protein, impeding the ROS production. This finding signifies a so far unrecognized protective role of this protein in the brain.
\end{abstract}

Keywords: Copper $\cdot$ Metallothionein-3 $\cdot$ Metal-thiolate cluster $\cdot$ Neurodegeneration $\cdot$ Oxidative stress

Dysregulation of metal homeostasis, abnormal metal-protein interactions, protein misfolding and aggregation are critical common etiopathological features in the progression of several neurodegenerative pathologies. ${ }^{[1-4]}$ Insoluble protein deposits and diffusible oligomers observed in various metal-linked neuronal diseases are composed of individual amyloidogenic proteins or peptides such as the amyloid- $\beta$ peptides $(\mathrm{A} \beta)$, a major component of extracellular amyloid plaques in Alzheimer (AD), prion protein in prion deposits typi-

\footnotetext{
${ }^{*}$ Correspondence: Dr. G. Meloni; Prof. Dr. M. Vašák University of Zurich

Department of Biochemistry

Winterthurerstrasse 190

$\mathrm{CH}-8057$ Zürich

Tel.: + 41446355552

Fax: +41446355905

E-mail: gmeloni@bioc.uzh.ch; mvasak@bioc.uzh.ch
}

cal of Creutzfeldt-Jakob, $\alpha$-synuclein in intracellular Lewy body in Parkinson (PD), superoxide dismutase (SOD) aggregates in amyotrophic lateral sclerosis (ALS) and Huntington inclusions in cases of Huntington diseases. Mounting evidence indicates that metals like $\mathrm{Cu}$ and $\mathrm{Zn}$ are involved in the progression of these degenerative diseases by modulating the formation and toxicity of amyloid oligomers and aggregates.

In contrary to diamagnetic redox-inert zinc, copper due to its redox-active nature $(\mathrm{Cu}(\mathrm{I}) / \mathrm{Cu}(\mathrm{II}))$ can react with molecular oxygen $\left(\mathrm{O}_{2}\right)$ resulting in the generation of reactive oxygen species (ROS) such as superoxide, hydrogen peroxide, and hydroxyl radicals through Fenton- and Haber-Weiss chemistry. ${ }^{[5,6]}$ The redox cycling of copper requires its reduction by biological components including ascorbate, which actively accumulates in the brain at concentrations between $0.5-10 \mathrm{mM},{ }^{[7]}$ catecholamines, cholesterol or other biological reducing agents. Altered copper homeostasis and free-radical production have been found in neurodegenerative disorders. This is paralleled by the presence of markers of diffuse oxidative stress and damage in the brain areas affected by the diseases. Hence, copper chelation and its redox-silencing may represent critical events in preventing the progression of neurodegenerative processes. In recent years, a metal chelation therapy emerged as a promising tool to attenuate abnormal metal-protein interactions that lead to increased free-radical toxicity. ${ }^{[6]}$

Metallothionein-3 (Zn $\left.{ }_{7} \mathrm{MT}-3\right)$, also known as the neuronal growth inhibitory factor (GIF), is highly expressed in the central nervous system, where it plays an important role in the homeostasis of the essential metal ions $\mathrm{Cu}$ (I) and $\mathrm{Zn}$ (II) and neuronal outgrowth. ${ }^{[8,9]}$ MT-3 binds with a high affinity essential monovalent and divalent $\mathrm{d}^{10}$ metal ions $\mathrm{Cu}(\mathrm{I})$ and $\mathrm{Zn}(\mathrm{II})$. Zn ${ }_{7}$ MT-3 structure contains two metalthiolate clusters localized in two independent protein domains. $\mathrm{AZn}_{3}(\mathrm{CysS})_{9}$ cluster is present in the $\mathrm{N}$-terminal $\beta$-domain and a $\mathrm{Zn}_{4}(\mathrm{CysS})_{11}$ cluster in the C-terminal $\alpha$-domain. ${ }^{[10-12]}$ Less detailed structural information is available regarding the structure of $\mathrm{Cu}(\mathrm{I})$-thiolate clusters in MT-3. The spectroscopic characterization of native $\mathrm{Cu}(\mathrm{I}), \mathrm{Zn}_{3-4} \mathrm{MT}-3$ isolated from brain and that of $\mathrm{Cu}_{(\mathrm{I})}, \mathrm{Zn}_{4} \mathrm{MT}-3$ generated in vitro revealed the presence of two homometallic metal-thiolate clusters located in two protein domains; a $\mathrm{Cu}(\mathrm{I})_{4}$-thiolate cluster in 
the N-terminal $\beta$-domain and a $\mathrm{Zn}(\mathrm{II})_{4}-$ thiolate cluster in the $\mathrm{C}$-terminal $\alpha$-domain. A digonal and trigonal $\mathrm{Cu}(\mathrm{I})$ coordination by cysteine sulfurs in the $\mathrm{Cu}(\mathrm{I})_{4}$-thiolate cluster of MT-3 has been inferred from the EXAFS and spectroscopic studies of $\mathrm{Cu}(\mathrm{I})$ containing mammalian MTs. ${ }^{[9,13-18]}$ To play a role in the metabolism of copper in extracellular space and to react with $\mathrm{Cu}(\mathrm{II})$-binding peptides/proteins involved in neurodegenerative disorders, MT-3 should react with $\mathrm{Cu}(\mathrm{II})$ ions.

In our studies, we showed that the thiolate-disulfide couple in MT-3 represents an efficient system linking zinc-thiolate cluster reactivity to $\mathrm{Cu}(\mathrm{II}) / \mathrm{Cu}(\mathrm{I})$ homeostasis. By detailed spectroscopic and biochemical investigations of $\mathrm{Zn}_{7} \mathrm{MT}-3$ reactivity towards free $\mathrm{Cu}$ (II) ions, we demonstrated that $\mathrm{Zn}_{7} \mathrm{MT}-3$ in a well defined process efficiently scavenges free $\mathrm{Cu}$ (II) ions. In this reaction $\mathrm{Cu}$ (II) is reduced to $\mathrm{Cu}$ (I) by thiolate ligands concomitant with their oxidation to disulfides and $\mathrm{Zn}$ (II) release. Owing to the redox nature of the coordinating thiolate ligands in $\mathrm{Zn}$ (II)-thiolate clusters and their high nucleophilicity, the sulfur oxidation represents the source of electrons for $\mathrm{d}^{9}$ $\mathrm{Cu}$ (II) reduction to $\mathrm{Cu}(\mathrm{I})$ and the consequent $\mathrm{Cu}(\mathrm{I})$ binding to the protein. By immunochemical methods, we could show that the $\mathrm{Cu}(\mathrm{I})_{4}$-thiolate cluster is located in the Nterminal $\beta$-domain of $\mathrm{Cu}(\mathrm{I})_{4} \mathrm{Zn}_{4} \mathrm{MT}-3 .{ }^{[19]}$ The binding of the first four $\mathrm{Cu}$ (II) is cooperative, forming a $\mathrm{Cu}(\mathrm{I})_{4}$-thiolate cluster in the $\beta$-domain of $\mathrm{Cu}_{4}, \mathrm{Zn}_{4}$ MT-3 together with two disulfides bonds. The $\mathrm{Cu}(\mathrm{I})_{4}$-thiolate cluster exhibits an unusual stability towards air oxygen. The formation of the $\mathrm{Cu}(\mathrm{I})_{4}$-thiolate cluster completely quenches the copper-driven free hydroxyl radical production. As the $\alpha$-domain still contains four $\mathrm{Zn}$ (II) ions, we suggest that the two disulfide bonds ought to be present in the $\beta$-domain. The presence of two disulfides in the $\beta$-domain, leaving five reduced thiolate ligands, would be sufficient to coordinate four $\mathrm{Cu}(\mathrm{I})$ ions through terminal and bridging sulfurs in digonal and/or trigonal coordination. A direct involvement of disulfide sulfur(s) in $\mathrm{Cu}(\mathrm{I})$ coordination cannot be excluded, as in inorganic model complexes a $\mathrm{Cu}(\mathrm{I})$ coordination by a disulfide has been observed. ${ }^{[20,21]}$ Nevertheless, the stability of the $\mathrm{Cu}(\mathrm{I})_{4}$-thiolate cluster in air oxygen is striking. The structural constraints imposed by the polypeptide chain and the short $\mathrm{Cu}(\mathrm{I}) \cdots \mathrm{Cu}(\mathrm{I})$ distances $(<2.8 \AA)$ observed in the $\mathrm{Cu}(\mathrm{I})_{4}-$ thiolate cluster lead to d-d orbital overlap and thus metal-metal interactions. This feature may be important for the unusual stability of $\mathrm{Cu}(\mathrm{I})_{4}$-thiolate cluster. ${ }^{[19]}$ In addition, the ability of MT-3 structure to accommodate widely different coordination geometries such as those for $\mathrm{Cu}(\mathrm{I})$ (digonal, trigonal) and $\mathrm{Zn}$ (II) (tetrahedral) in its metal-thio-

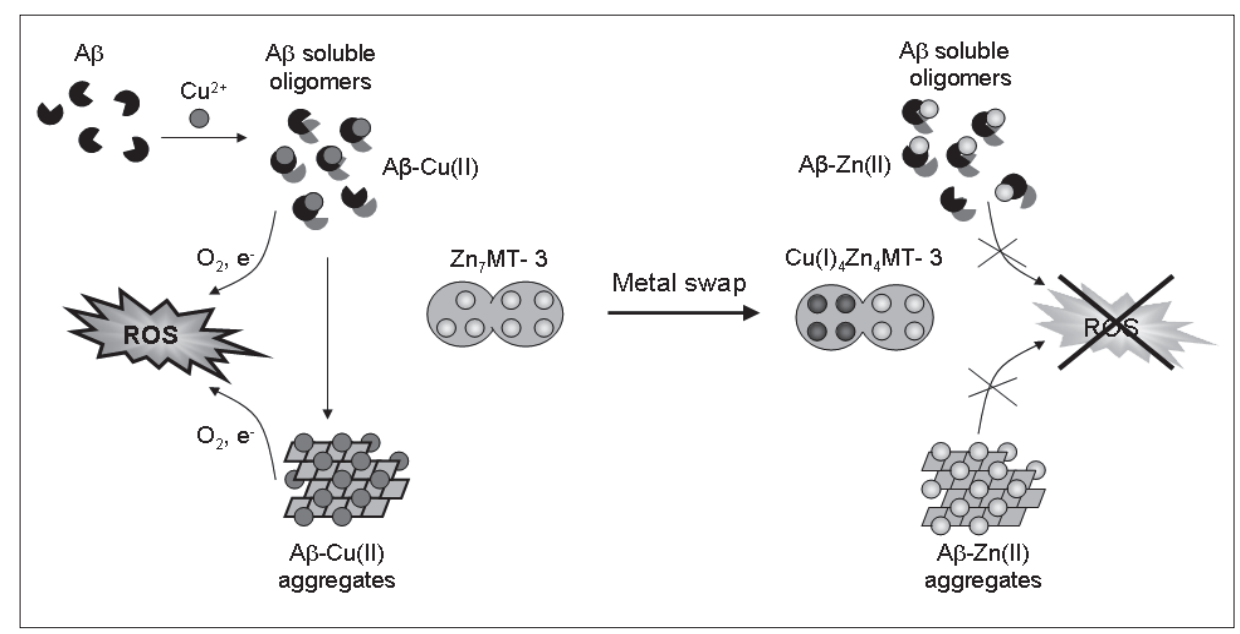

Fig. Simplified scheme showing the metal swap reaction between $\mathrm{Zn}_{7} \mathrm{MT}-3$ and $\mathrm{A} \beta-\mathrm{Cu}(\mathrm{II})$ generating $\mathrm{Cu}(\mathrm{I})_{4} \mathrm{Zn} \mathrm{n}_{4} \mathrm{MT}-3$ and $\mathrm{A} \beta-\mathrm{Zn}(\mathrm{I})$. The influence of the reaction on the $A \beta-\mathrm{Cu}(I)$ catalyzed ROS production is highlighted.

late clusters affords the structural bases for the reaction. Thus, $\mathrm{Zn}_{7} \mathrm{MT}-3$ through the silencing of redox-active $\mathrm{Cu}(\mathrm{II})$ ions may play an important protective role from $\mathrm{Cu}(\mathrm{II})$ toxicity in the brain.

The $\mathrm{Zn}_{7} \mathrm{MT}-3$ reaction may be important under neuropathological conditions in which a dysregulation of copper homeostasis occurs. In the brain, $\mathrm{Zn}_{7} \mathrm{MT}-3$ is localized in neurons, astrocytes and in the extracellular space in comparable amounts ${ }^{[22]}$ and was found down-regulated in AD. [23] A hallmark of $\mathrm{AD}$ brains is the presence of extracellular $\beta$-amyloid plaques rich in metals such as $\mathrm{Zn}$ and $\mathrm{Cu} .{ }^{[2]}$ These fibrillar deposits are mainly composed of a 39-43 residue $\mathrm{A} \beta$ peptide, generated by proteolytic processing of the amyloid precursor protein (APP) by $\beta$ - and $\gamma$-secretases. ${ }^{[2]}$ $\mathrm{A} \beta$ peptides can interact with metal ions thereby participating in their aggregation and in the production of ROS. ${ }^{[2]}$ Whereas the copper-induced $A \beta$ aggregation is the source for ROS production and neurotoxicity, ${ }^{[24]}$ the zinc-induced $A \beta$ aggregation is believed to be neuroprotective. ${ }^{[25]} \mathrm{Zn}_{7}$ MT-3 can rescue neuronal cells from the toxicity of $A \beta_{1-40}$ peptide. ${ }^{[26]}$ As the toxicity of $A \beta$ stems from the ROS production by $\mathrm{A} \beta-\mathrm{Cu}(\mathrm{II})$, we hypothesized that a transmetallation between $\mathrm{A} \beta-\mathrm{Cu}$ (II) and $\mathrm{Zn}_{7}$ MT-3 could be the underlying molecular mechanism.

By using complementary spectroscopic, biochemical and cell biological techniques we showed that Zn $\mathrm{n}_{7}$ MT-3 can efficiently reduce and remove $\mathrm{Cu}$ (II) from $\mathrm{A} \beta-\mathrm{Cu}$ (II) via a metal swap reaction, in which oxygen stable $\mathrm{Cu}(\mathrm{I})_{4} \mathrm{Zn}_{4} \mathrm{MT}-3$ and redox inert $\mathrm{A} \beta-\mathrm{Zn}$ (II) are generated. Similarly to the reaction of $\mathrm{Zn}_{7} \mathrm{MT}-3$ with free $\mathrm{Cu}$ (II), the generated $\mathrm{Cu}(\mathrm{I})_{4} \mathrm{Zn}_{4} \mathrm{MT}-3$ species contains two disulfide bonds required for the reduction of four $\mathrm{Cu}(\mathrm{II}) .^{[27]}$ The metals swap reaction occurs with both soluble and oligomeric $\mathrm{A} \beta-\mathrm{Cu}(\mathrm{II})$ species, which are thought to be the initial and most toxic species generated in the $A \beta$ aggregation pathway prior to the formation of insoluble aggregated $\mathrm{A} \beta-\mathrm{Cu}(\mathrm{II})$. This reaction also quenches the redox activity of $\mathrm{A} \beta-\mathrm{Cu}$ (II) and the ROS production. As a consequence, the demonstrated increased solubility of the generated $A \beta-\mathrm{Zn}$ (II) suggests that the formation of SDS insoluble $A \beta$ aggregates and $A \beta$ dityrosine cross-links occurring in AD brains would be significantly reduced. [27]

Cell viability assays using human SHSY5Y neuroblastoma cells revealed that the toxic effect of $\mathrm{A} \beta-\mathrm{Cu}$ (II) could be markedly reduced by the addition of $\mathrm{Zn}_{7} \mathrm{MT}-3$, but not the fully $\mathrm{Cu}(\mathrm{I})$-loaded $\mathrm{Cu}(\mathrm{I})_{8} \mathrm{MT}-3$ form which is unable to remove copper from $\mathrm{A} \beta$. Both $\mathrm{Cu}(\mathrm{II}) \mathrm{EPR}$ and $\mathrm{Cu}(\mathrm{I})$ luminescence measurements carried out on cell culture samples confirmed the metal swap. Overall, the metal swap between $\mathrm{Zn}_{7} \mathrm{MT}-3$ and $\mathrm{A} \beta-\mathrm{Cu}(\mathrm{II})$, accompanied by $\mathrm{Cu}(\mathrm{II})$ reduction and binding into the protein structure, is the mechanism by which the ROS production and related cellular toxicity are quenched (Fig.).

A similar protective effect of $\mathrm{Zn}_{7} \mathrm{MT}-3$ can be predicted for other metal-linked neurodegenerative pathologies such as transmissible spongiform encephalopathies (TSEs, also known as prion diseases) and PD, in which altered MT-3 levels and the dysregulated copper metabolism occur. ${ }^{[28,29]}$ The prion diseases, a group of progressive neurodegenerative disorders that affect the brain and nervous system of humans and animals, are transmitted by prions, proteinaceous infective agents. ${ }^{[30]}$ Prion diseases result from the accumulation of a misfolded form of the endogenous prion protein $\left(\mathrm{PrP}^{\mathrm{C}}\right)$. The transition from natively folded $\operatorname{PrP}^{\mathrm{C}}$ to misfolded $\mathrm{PrP}^{\mathrm{Sc}}$ is a crucial pathogenic event. ${ }^{[31]}$ The misfolded prion protein is the major constituent of the extracellular TSEs plaques. Experimental evidence suggests that oxidative stress, as- 
sociated with the copper-catalyzed transformations of prion protein, is involved in these degenerative processes. In the human $\operatorname{PrP}^{\mathrm{C}}$ structure, besides $\alpha$-helix and $\beta$-sheet structure, about $50 \%$ mainly disordered structure is present in the N-terminal part. The disordered part contains four $\mathrm{HG}$ GGW octarepeats and can bind up to six $\mathrm{Cu}(\mathrm{II})$ ions. Each octarepeat is involved in the coordination of one $\mathrm{Cu}$ (II) through the imidazole nitrogen of histidine, two glycine amide nitrogens and carbonyl oxygen in a square planar geometry. Additional two copper binding sites are present outside of the octarepeat region. However, depending on copper concentrations a lower binding occupancy and different modes of metal binding occur. Thus, distinct interor intra-octarepeat $\mathrm{Cu}$ (II) square planar binding modes involving, besides other ligands, more than one histidine from different octarepeats are formed. These complexes show a different affinity for $\mathrm{Cu}$ (II), ranging from $0.1 \mathrm{nM}$ to $\sim 10 \mu \mathrm{M} .{ }^{[32]}$ Studies conducted in our lab using different peptides, mimicking the $\mathrm{Cu}$ (II) binding modes in PrP, indicate that a metal swap between $\mathrm{Zn}_{7} \mathrm{MT}-3$ and PrP-Cu(II) also occurs. This reaction can modulate not only the $\mathrm{PrP}$ structure and its reactivity with oxygen, but also the ROS production and related toxicity (manuscript in preparation).

In the pathology of $\mathrm{PD}$, the aggregation of $\alpha$-synuclein is a key process in the formation of intracellular inclusions, Lewy bodies, in dopaminergic neurons of substantia nigra. ${ }^{[33]}$ Studies conducted on hemi-Parkinsonian rats suggest that the free radical scavenging potency, including that of MT-3, is reduced in the Parkinson brain which accelerates the progression of PD. ${ }^{[34]}$ The demonstrated copper binding to $\alpha$-synuclein and accompanied oxidative stress may contribute to an abnormal aggregation of this molecule. The high affinity $\mathrm{Cu}$ (II) binding site in $\alpha$-synuclein is located at the $\mathrm{N}$-terminus in which $\mathrm{Cu}$ (II) is anchored through the residues Met ${ }_{1}$, Asp and other ill-defined nitrogen/oxygen donor atoms in a square planar or distorted tetragonal geometry.[4] Evidence for the direct involvement of copper in $\alpha$-synuclein aggregation and in the generation of ROS comes from studies showing that

i) $\mathrm{Cu}(\mathrm{II})$ induces self-oligomerization of $\alpha$-synuclein,

ii) $\alpha$-synuclein- $\mathrm{Cu}(\mathrm{II})$ generates hydrogen peroxide via Fenton-type reaction and

iii) that lipids, in the presence of $\mathrm{Cu}$ (II) and $\mathrm{H}_{2} \mathrm{O}_{2}$, enhance the metal-catalyzed oxidative self-oligomerization of $\alpha$-synuclein.

The latter is an important event as it leads to the dissociation of $\alpha$-synuclein from the cell membrane and its aggregation in the cytosol.[35-37] $\mathrm{Zn}_{7} \mathrm{MT}-3$, in a similar type of reaction as described above, is capable of modulating abnormal synuclein-Cu(II) interactions thereby influencing the redox activity of $\alpha$-synuclein, its aggregation and oxidative modification of $\alpha$-synuclein and catecholamine (manuscript in preparation).

Taken together, the finding that MT-3 exerts multiple functions, including the maintenance of zinc and copper homeostasis and the protection against reactive oxygen species, supports protective roles of this protein in the progression of different metal-linked neurodegenerative disorders. Therapeutic strategies aiming at ameliorating or inhibiting redox chemistry induced by metal-protein complexes involved in neurodegenerative processes are currently pursued. These include the use of antioxidants and metal complexing agents. The discovered protective effect of $\mathrm{Zn}_{7} \mathrm{MT}-3$ suggests that up-regulation of the MT-3 expression, targeting of exogenous $\mathrm{Zn}_{7}$ MT-3 to the central nervous system, and/ or the design of drugs mimicking the MT3 chemistry may lead to new therapeutic strategies in the treatment of metal-linked neurodegenerative disorders.

\section{Acknowledgements}

This work is supported by the Forschungskredit der Universität Zürich Grant 54043901, Swiss National Science Foundation Grant 3100A0-100246/1 and the Hartmann Müller-Stiftung.

Received: December 19, 2008

[1] A. I. Bush, Trends Neurosci. 2003, 26, 207.

[2] P. A. Adlard, A. I. Bush, J. Alzheimers Dis. 2006, 10,145 .

[3] D. R. Brown, H. Kozlowski, Dalton Trans. 2004, 1907.

[4] A. Binolfi, G. R. Lamberto, R. Duran, L. Quintanar, C. W. Bertoncini, J. M. Souza, C. Cervenansky, M. Zweckstetter, C. Griesinger, C. O. Fernandez, J. Am. Chem. Soc. 2008, 130 , 11801.

[5] E. Gaggelli, H. Kozlowski, D. Valensin, G. Valensin, Chem. Rev. 2006, 106, 1995.

[6] K. J. Barnham, C. L. Masters, A. I. Bush, Nat. Rev. Drug. Discov. 2004, 3, 205.

[7] M. E. Rice, Trends Neurosc. 2000, 23, 209.

[8] M. Vašák, D. W. Hasler, Curr. Opin. Chem. Biol. 2000, 4, 177.

[9] Y. Uchida, K. Takio, K. Titani, Y. Ihara, M. Tomonaga, Neuron 1991, 7, 337.

[10] G. Öz, K. Zangger, I. M. Armitage, Biochemistry 2001, 40, 11433.

[11] P. Faller, D. W. Hasler, O. Zerbe, S. Klauser, D. R. Winge, M. Vašák, Biochemistry 1999, 38, 10158

[12] H. Wang, Q. Zhang, B. Cai, H. Li, K. H. Sze, Z. X. Huang, H. M. Wu, H. Sun, FEBS Lett. 2006, 580,795

[13] D. L. Pountney, I. Schauwecker, J. Zarn, M. Vašák, Biochemistry 1994, 33, 9699.

[14] A. Presta, M. J. Stillman, Chirality 1994, 6, 521.

[15] R. Bogumil, P. Faller, D. L. Pountney, M. Vašák, Eur. J. Biochem. 1996, 238, 698.

[16] R. Bogumil, P. Faller, P. A. Binz, M. Vašák, J. M. Charnock, C. D. Garner, Eur. J. Biochem. 1998, 255, 172.

[17] B. Roschitzki, M. Vašák, J. Biol. Inorg. Chem. 2002, 7, 611 .
[18] B. Roschitzki, M. Vašák, Biochemistry 2003, 42, 9822.

[19] G. Meloni, P. Faller, M. Vašák, J. Biol. Chem 2007, 282, 16068.

[20] C. Belle, W. Rammal, J. L. Pierre, J. Inorg. Biochem. 2005, 99, 1929.

[21] T. Ohta, T. Tachiyama, K. Yoshizawa, T Yamabe, T. Uchida, T. Kitagawa, Inorg. Chem. 2000, 39, 4358.

[22] Y. Uchida, F. Gomi, T. Masumizu, Y. Miura, $J$. Biol. Chem. 2002, 277, 32353.

[23] W. H. Yu, W. J. Lukiw, C. Bergeron, H. B. Niznik, P. E. Fraser, Brain Res. 2001, 894, 37.

[24] X. Huang, M. P. Cuajungco, C. S. Atwood, M. A. Hartshorn, J. D. Tyndall, G. R. Hanson, K. C. Stokes, M. Leopold, G. Multhaup, L. E. Goldstein, R. C. Scarpa, A. J. Saunders, J. Lim, R. D. Moir, C. Glabe, E. F. Bowden, C. L. Masters, D. P. Fairlie, R. E. Tanzi, A. I. Bush, J. Biol. Chem. 1999, 274, 37111.

[25] M. P. Cuajungco, L. E. Goldstein, A. Nunomura, M. A. Smith, J. T. Lim, C. S. Atwood, X. D Huang, Y. W. Farrag, G. Perry, A. I. Bush, J. Biol. Chem. 2000, 275, 19439.

[26] Y. Irie, W. M. Keung, Biochem. Biophys. Res. Commun. 2001, 282, 416.

[27] G. Meloni, V. Sonois, T. Delaine, L. Guilloreau, A. Gillet, J. Teissie, P. Faller, M. Vašák, Nat Chem. Biol. 2008, 4, 366.

[28] C. A. Sogawa, M. Asanuma, N. Sogawa, I. Miyazaki, T. Nakanishi, H. Furuta, N. Ogawa, Acta Med. Okayama 2001, 55, 1.

[29] T. Kawashima, K. Doh-ura, M. Torisu, Y. Uchida, A. Furuta, T. Iwaki, Dement. Geriatr. Cogn. Disord. 2000, 11, 251.

[30] A. Aguzzi, M. Heikenwalder, Nat. Rev. Microbiol. 2006, 4, 765.

[31] S. B. Prusiner, Science 1982, 216, 136

[32] G. L. Millhauser, Annu. Rev. Phys. Chem. 2007, $58,299$.

[33] T. M. Dawson, V. L. Dawson, Science 2003 $302,819$.

[34] I. Hozumi, M. Asanuma, M. Yamada, Y. Uchida, J. Health Sci. 2004, 50, 323.

[35] S. R. Paik, H. J. Shin, J. H. Lee, C. S. Chang, J. Kim, Biochem. J. 1999, 340, 821

[36] S. R. Paik, H. J. Shin, J. H. Lee, Arch. Biochem. Biophys. 2000, 378, 269.

[37] S. Turnbull, B. J. Tabner, O. M. El-Agnaf, S. Moore, Y. Davies, D. Allsop, Free. Radic. Biol. Med. 2001, 30, 1163 . 